https://doi.org/10.31470/2706-7904-2021-16-184-188

\title{
ЗАСТОСУВАННЯ СТОРІТЕЛІНГУ ЯК ТЕХНОЛОГІЇ ЕФЕКТИВНОӤ КОМУНІКАЦІЙ ЗІ СТУДЕНТАМИ-ФІЛОЛОГАМИ
}

\author{
Using Storytelling as a Technology for Effective Communication with \\ Philology Students
}

\author{
Liubov Letiucha \\ Ph.D. in Philology, Associate Professor \\ Hryhorii Skovoroda University in Pereiaslav (Ukraine) \\ letinna@ukr.net \\ https://orcid.org/0000-0002-0481-850X
}

\begin{abstract}
Storytelling is a term used by marketers, journalists, psychologists and teachers, and understood as a communication technology where narration makes information interesting and memorable for the recipient. The article analyses peculiarities of the storytelling phenomenon in the philological lecture discourse. It systematizes its most typical characteristics. We used such methods discursive analysis, as well as methods of observation, systematization and classification. The study has revealed and described storytelling language means that philology lecturers use. The peculiarity of this phenomenon is emotional-and-evaluative and factual information combined by means of action verbs, as well as a dialogically expressed discourse through the elements of direct speech, the inclusive pronoun "we», rhetorical questions and exclamatory constructions. After analyzing the material, we came to the conclusion that it is expedient to use the storytelling phenomenon both in the educational environment in general and philology lecture discourse in particular.
\end{abstract}

Key words: storytelling, narrative, lecture discourse, psychological factor.

\section{Вступ \\ Introduction}

Безперечно, що у процесі навчання найбільшою мотивацією для учнів \студентів є інтерес (зацікавленість) (Hidi \& Renninger, 2006: 112), що створює «психологічно комфортний режим розумової праці» (Холодна \& Гельфман, 2016: 51).

Оскільки текст $є$ одним із основних способів передачі знань студентамфілологам, все більше фахівців сходяться на думці, що навчальний текст має бути 
цікавим, емоційним (Холодна \& Гельфман, 2016: 36-40). Ученими виявлено велику кількість вербальних прийомів, здатних викликати неабиякий інтерес та зацікавленість. Одним із таких актуальних прийомів є стратегія сторітелінгу, яку в 90$\mathrm{x}$ p. XX ст. розробив і успішно впровадив в управління міжнародною корпорацією американець Девід Армстронг. Головним у розробленій стратегії був психологічний чинник: розповіді з життя значно краще сприймаються, вони цікавіші, ніж сухі, логічні аргументи, а тому здатні викликати в слухача неабияку довіру й мотивувати до певних дій.

У науковій літературі сторітелінг першочергово визначається як технологія ефективних комунікацій, маркетинговий інструмент, інформаційно-комунікативна технологія наративної комунікації, що використовується як інструмент управління персоналом тощо. Та сьогодні все частіше звучить думка, що технологія, яка розроблена для менеджменту та маркетингу, може бути корисною і в галузі освіти, оскільки подання матеріалу за допомогою розповіді створює умови для мотивації до навчання.

Метою статті $\epsilon$ визначення особливостей сторітелінгу як сучасної комунікативної технології та спроба визначення його статусу в освітньому середовищі, а саме виявлення засобів його вираження в лекційному дискурсі.

\section{Методи та методики дослідження Methods and Techniques of the Research}

У пропонованому дослідженні застосовано метод дискурсивного аналізу, а також методи спостереження, систематизації та класифікації, за допомогою яких було виявлено основні показники та засоби вираження сторітелінгу у філологічному лекційному дискурсі.

\section{Результати \\ Results}

Зарубіжні дослідники відзначають успішність освітнього підходу, заснованого на сторітелінгу, особливо під час навчання студентів іноземної мови, а також при розвитку навичок творчого та навіть академічного письма (Mlynarczyk, 2014; Lin, 2014). На думку авторів ігнорувати місце цієї реалії у вищій школі - це свого роду неприйняття того, що стало частиною реальності і здатне викликати у студентів почуття розбіжності між повсякденним життям та академічним середовищем. Дослідники вважають, що цікава історія може стати цінним засобом навчання в академічному середовищі. 
До педагогічних плюсів сторітелінгу як стратегії навчання відносять: (1) сторітелінг містить елементи, які утримують інтерес студентів; (2) він допомагає розвивати цілий набір навичок грамотності з використанням соціальних елементів мови (тобто це жива мова, що враховує ролі учасників у визначеному контексті ситуації); (3) сторітелінг може формувати почуття причетності та різноманіття, так як за своєю суттю це мультижанровий та мультимодальний феномен, що стимулює свободу уяви в аудиторії (Lin, 2014).

Щоб утримати увагу аудиторії наратор, на думку вищезгаданого дослідника, повинен зацікавити слухачів питаннями, порівняннями, міркуваннями та вивести всю аудиторію на рівень сторітелінгу.

М. Далстром (Dahlstrom, 2014) зазначає, що сторітелінг - дуже важлива стратегія передачі інформації в науковому середовищі, коли потрібно здійснити перехід від отриманих даних до викладу їхнього змісту, до опису. Будучи заснованим на наративних стратегіях, він має персуазивний ефект, опирається на індуктивний хід думки (логіки), контекстуально залежний, має «тріумвірат» характеристик причинність, тимчасову віднесеність та наявність персонажа (персонажів). Історія, як правило, базується на особистому досвіді оповідача, що визначає ступінь правдивості. Будучи схильним до драматизації, здатності викликати емоції, володіючи персоніфікацією та фантазійністю, сторітелінг робить інформацію такою, що запам'ятовується і тому може бути ефективно використаний в освітньому середовищі.

У ХX ст. з'явилася концепція, що вивчає специфіку розповіді, оповідання, а саме наративна концепція, пов'язана 3 особливою композицією (структурною організацією) тексту, що розповідає про дії героїв (Herman, 2005).

У лекційному дискурсі, на нашу думку, абсолютно логічно та необхідно застосовувати сторітелінг, виділяючи наступні його показники: (а) наявність історії, наповненої емоціями, з дійовими особами; (б) залучення лектора в цю історію (сторітелінг покликаний демонструвати події реальності із опорою на особистий досвід); (в) ускладнення ситуації та розв’язка, яка вплине на розуміння теми лекції аудиторією.

Ураховуючи ці показники, здається доречним зупинитися на засобах вираження сторітелінгу у філологічному лекційному дискурсі.

Наратив обов'язково містить фактичну інформацію лінгвістичного характеру, оскільки ми говоримо про лекційний контекст філологічного спрямування. Вступна частина лекції, що інформує про контекст та учасників історії, може виглядати наступним чином: Тема у нас незвичайна, погодьтеся тощо. Доречним буде в формуванні зацікавленності ускладнити ситуацію, наприклад, герой-лектор стикається з нерозумінням студентів важливості вивчення мов тощо. 
Формат сторітелінгу дозволяє лекторам успішно демонструвати свої емоції, які вони відчували у контексті описаної ситуації і стосовно до обговорюваного феномену загалом. Лектор може використовувати таку емоційну лексику, що демонструє безпосередньо його власне відношення до історії лекції: приємно, із задоволенням, розумно, жах, біда, пишаюся тощо. Це призводить до залучення самого лектора до складу дійових осіб. Реальність історії зберігається за рахунок вже зазначеної фактичної інформації та дієслів дії (не просто перебування), які допомагають аудиторії візуалізувати описувані події, наприклад: продзвенів дзвінок, все розпочалось, я прийшла читати лекиї тощо. Завдяки формату сторітелінгу, у кінці історії після ускладнення та розв'язки стає очевидною точка зору лектора: наприклад, завершення історії з особистого досвіду: тоді цзе було для нас зовсім незвично, я пам'ятаю, студент розповів про свою першу поӥздку за кордон тощо.

Для наочності історій, використовуваних лекторами під час обговорення питань 3 теми лекції та для утримання уваги аудиторії, характерні підвищена діалогізація 3 використанням прямої мови та інклюзивного займенники «ми», риторичні питання та окличні конструкції.

Підвищена діалогізація дискурсу активізує залучення аудиторії до змісту лекції, що досягається за допомогою включення в історію прямої мови: він відповів, я запитала тощо. Саме присутність прямої мови в наративі дозволяє авторам висловити свої емоції, своє ставлення. Це активізує, як вже було відзначено вище, причетність аудиторії, якій стає цікаво, чим же скінчиться цікава історія. Важливо також відзначити, що сторітелінг наближає лектора до студентів, а це, у свою чергу, також може бути передумовою для налагодження успішної комунікації із аудиторією. Сучасний американський вчений та поет - професор Х. Сворд для конструювання успішного академічного дискурсу рекомендує вживати конкретну мову (особливо іменники та дієслова, які дають можливість адресату візуалізувати об'єкти, дії, а також жарти і анекдоти із власного досвіду, що надасть дискурсу індивідуальність (Sword, 2012).

Усе це демонструє, що завдяки сторітелінгу освітня лекція перетворюється у захоплюючий та діалогізований процес передачі інформації, що ілюструє осмислене обговорення певних питань за допомогою особистого досвіду.

\section{Висновки \\ Conclusions}

Сторітелінг - активно використовуваний у сучасній науці та професійній практиці термін. Дослідження витоків сторітелінгу можна знайти в наукових працях, 
присвячених вивченню наративу, що визначається, як правило, засобом реалізації комунікативної технології сторітелінгу. У зв’язку з тим, що ми маємо безліч каналів, що передають різноманітність інформації, утримувати увагу сучасної аудиторії стає все складніше. Увага людини фокусується на цікавій історії, відповідно, технологія сторітелінга, що є давньою і природною практикою людської комунікації, на нашу думку, може визначатися як одне з ефективних засобів комунікування інформації і при викладанні філологічних дисциплін.

\section{Література} References

Dahlstrom, M. Using narratives and storytelling to communicate science with nonexpert audiences. Retrieved from http://www.pnas.org/content/111/Supplement_4/13614 (accessed 27.11.2021). https://doi.org/10.1073/pnas.1320645111

Herman, D. (2005) Histories of Narrative Theories (1): A Genealogy of Early Developments, A Companion to Narrative Theory, Blackwell Publ, 19-35. https://doi.org/10.1002/9780470996935.ch2

Hidi, S., \& Renninger, K.A. (2006). The Four-Phase Model of Interest Development. Educational Psychologist, 41(2), 111-127. https://doi.org/10.1207/s15326985ep4102_4

Lin, C.C. (2014) Storytelling as Academic Discourse: Bridging the Cultural-Linguistic Divide in the Era of the Common Core. Journal of Basic Writing, 33(1), 4-22. https://doi.org/10.37514/JBW-J.2014.33.1.04

Mlynarczyk, R.W. (2014). Storytelling and Academic Discourse: Including More Voices in the Conversation, Journal of Basic Writing, 33(1), 52-73. https://doi.org/10.37514/JBWJ.2014.33.1.02

Sword, H. ( 2012) Stylish Academic Writing. Cambridge: Harvard Univ. Press. https://doi.org/10.4159/harvard.9780674065093

Холодная, М.А., \& Гельфман, Э.Г. (2016). Развивающие учебные тексты как средство интеллектуального воспитания учащихся. Москва: Ин-т психологии Рос. акад. наук. 